\title{
Journal of the Textile Machinery Society
}

Vol. 12, No. $5 \quad$ (No. 119) May. 1959

\section{Contents}

\section{Reviews}

I. Kaino: Textlle Products as They are Today and How They Should be in Future....... 1

\section{Technical Papers}

\section{S. Yamawaki, K. Fujino: Fibre Transfor Action of Rollers in a Garding Machine.}

Part 1. \section{6}

Systematic experiments regarding two important interacting portions, i.e., between the transporter and the cylinder, and between the cylinder and the dolfer, have been made on a model carding machine, the collecting power being culculated on the basis of the weighted values of fibre layer thickness on rollers. As a result, some interesting aspects have been observed as to how the collecting power is intluenced by various carding conditions. They are:

(1) When metallic wire is used, collecting power shows a continuous growth as the leed increases. With card cloth, however, it shows a discontinuous change.

(2) Collecting power is scarecely influenced by the gauge between two interacting rollers, but influenced largely by their peripheral speed ratio.

\section{S. Yamawaki, G..Hirose: Mechanisms of a Pneumatic Analyser and Its Fluid}

Dynamical Functions. Part 1.

A pneumatic analyser (Japanese Pat. No. 248962) is highly effective for the opening, cleaning and separating of fibres.

Its function has been examined from the standpoint of fluid dynamics. The following results have been obtained:

(1) From the relation between the taker-in speed and the circuitious radius of tibers, the effective limit of the taker-in speed has been established and found to be ronghly equal to that of the ordinary analyser.

(2) By investigating the motion of separated and falling fibrer, a device to prevent them from re-mixing with usable fibers has been obtained.

(3) The influence of the streamer plate and the regulating tongue on the air flow in the chamber is made clear from the velocity distribution curves.

The streamer plate has been found useful for keeping the separating zone effective as long as possible.

The regulating tongue operates successfully in order to bring usable fibers into the cage-suctionregion.

T. Murayama, S. Ono: Coefficient of Kinetic Friction of Yarn Studied by means of Automatic Recording Tester. Part 1: The frictional behavior of yarns running on other materials have been studied by measuring the coefficient of kinetic friction....24

Results :

(1) The frictional coefficient $\mu$ is determined trom the variation of tension $S_{1}, S_{2}$, by running yarn on three frictional materials, and substituting $S_{1}, S_{\text {z }}$ into the following formula, $\mu=\log \left(S_{2} / S_{1}\right) 2 \pi$ loge.

(2) The coetficient $\mu$ between raw silk and a duralumin cylinder is about $0.20 \sim 0.22$; between nylon and a duralmin cylinder, about $0.23 \sim 0.26$.

(3) The coefficient $\mu$ shows a tendency to increase with the increase of yarn speed.

(4) The coefficient of kinetic triction of yarn is influenced by the surface condition of the yarn, small deformation at the touch place of running yarn, electro static charge, and heat-up by friction. 


\section{ニューマチックアナライザの \\ 機構と流体力学的作用 (第 1 報)}

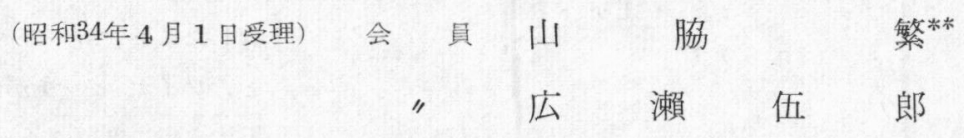

$\longrightarrow$ 摘 要

\section{研 究 目 的}

特許第 248962 号ニューマチック アナライザは,カシミヤ原毛の整毛装置として実用化され極めて有効なる“は たらき”をしているが，その機能を流体力学的見地から部分的に解析し検討を試みた。

\section{研 究 結 果}

（1）テーカインの速度と瀻維の旋回半径の関係から、テーカイン回転数の有効限界がわかり害用機のそれと一 致することが確認でさた。

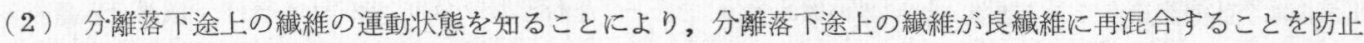
する方法の案出に役立った.

（3）整流板，整流翼のボックス内気流状態に与古る影響を風速分布形から知ることができた. そして分離帯域 をできるだけ長く保つことによって分離効果を良くするために整流板が，浮遊進行する良繊維を方向転換せしめて ケージの強制吸引力のおよら範囲むで上界せしめるために整流翼が、それぞれ有勃に作用していることを確認した.

\section{1. 緒}

\section{言}

最近紡績機械に気流の作用を応用して㵶維塊や瀻維を 処理する有勃なるものが製作され，その内外における研 究結果の発表も数多くなされている.

ここに報告するニューマチックアナライザもその一 つである.

本機はわが社の特許として登録 (特許第 248962 号)さ れ，主としてカシミヤ原毛の整毛装置として使用されて いるが，紡毛紡績用の羊毛ノイル中の異物，ネップ等の 分離除去装置としてもとの機能は極めて良好な結果を示 している.

本機は簡単な機構ではあるが，その機能は流体力学的 理論の裏付けにより，本機の作用の研究は，現用カード 機に羭けるカーデイング作用の流体力学的解明に役立つ いろいろの事項と, 将来のカード機の構造に益する要素 を発見するに有効である.

かかる見地から種々の実驗ならびに理論的検討を行な ってきたのであるが,ここにはその一部を第 1 報として
報告する.

\section{2. 機構の概略とその袎能}

第 1 図は本機の外観写真, 第 2 四はその要部の機構模 型である.

第 2 図でわかるように，直接の “はたらき”をする部 分の構造は極めて簡単である。

機構上第 2 図に現われていない二, 三の点について説

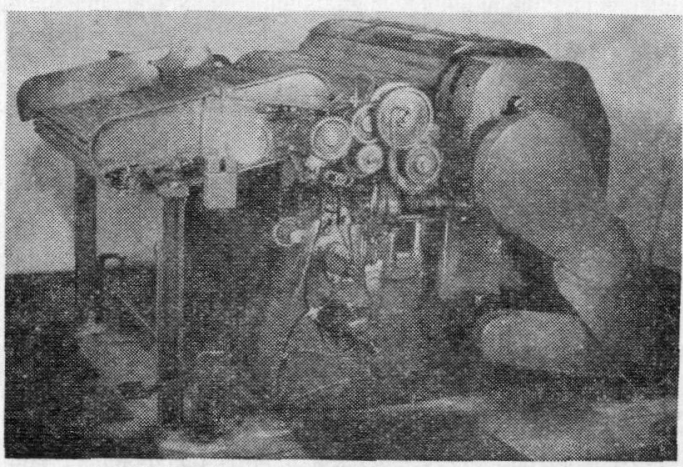

(第1図) 外 観 写 真

* Mechanisms of a Pneumatic Analyser and its Fluid Dynamical Functions. Part 1:

** S. Yamawaki, Member. G. Hirose, 大信紡績株式会社 


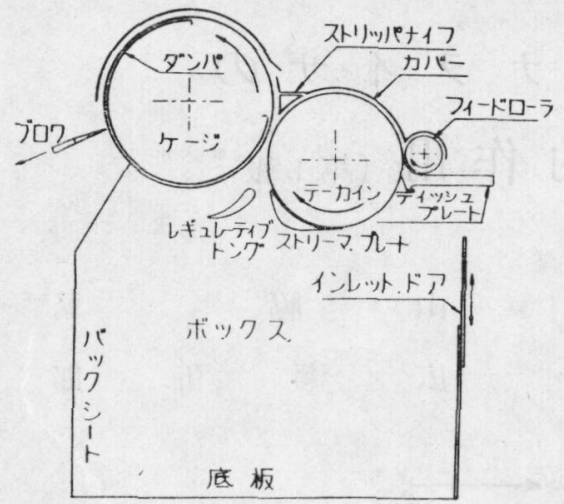

（第2図）機 構 模 型

明を加える。

テーカインローラはメタリックワイヤが密着巻きさ れている.

ストリーマプレート(以下整流板と称す) は固定であ るが、レギュレーティブトング（以下整流翼と称す）は 上下前後に全体の調節ができると共に，一端のみの調節 も可能である.

ケージローラ内のダンパは, その開口部の位置を自 在に変光得る.

インレットドフは開口度合を上下に調節し得る構造 でかっドアの上端は機台の内方向に特殊な形状をなし， 流入空気量が幅方向に常に均一になるごとく設計されて いる.

次に機能を大さく左右する機構上の要点を列記すると

(1) ディッシュプレートのローラ面の形状

(2) テーカインローラの回転数とメタリックワイ 十の形状

（3）整流板の形状と取付位置および先端ゲージ

（4）整流翼の形状と調節状態

(5) ケージローラ内ダンパの開口部位置と吸引の 強弱

（6）インレットドアの開口度合

（7）インレットドア面からバックシート面までの 距離を奥行，整流板下面から底板までの距離を 深さとすると、ボックス内の奥行対深さの割合 関係

本機はこれらの最適の相互関係において運転され，そ の性能が十分発揮されているのである.したがってこれ らの中 1 個所たりともその機能を停止するかむたは条件 を変化させるならば，直ちに本機の作用に悪影響を掞よ ぼすのである.すなわち極めて微妙なる機能を特つ装置 であると云える，
本機のテーカインローラに密着巻きするメタリック ワイヤには,わが社の特許として登録(特許第 239706 号) されている特種メタリックワイヤ(別報平面板状メタリ ック ワイヤの特性 第 1 報第 30 図参照) を用いている. このワイヤは円円メタリックワイヤと呼称し，特長 としてはローラの軸方向に齒を交互に高低状態に密着巻 きしたこと、ローラへの巻揚り腹角がほぼ直角であるこ と、ワイヤピッチが他のメタリックワイヤに比べて最 も大きいこと(グルーブピッチは一般メタリックワイ ヤにほほ等しい) 等である.

また特性としては、ディッシュプレートとローラ間 で空気の導入を許容し, 繊維塊に無理を与えずに解毛し (したがって繊維切れが少ない), 齒高ワイヤの軸方向の 間隔間に生ずる繊維の渦流現象を蒵低ワイヤが規正して 軸方向の口ーラ面全体の繊維束に均一飞波状流動を与之 纎維塊の分脑分散を促進して解舒を良好にし，異物の分 離を容易にすることである.

なおこのメタリックワイヤは, 纎維付着量の多少に かかわらず抵㧍係数にほとんど変化なく，一般メタリッ クワイヤの值に比べて小さい，これはワイヤ面からの 繊維の離れを適当に保って分滩效果に有效である。

第 3 図は，凸刚メタリックワイヤを密着巻きした本 機のテーカインローラの一部写真である.

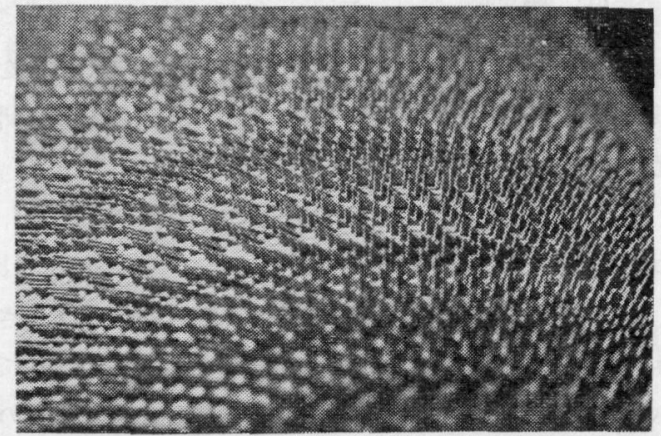

（第 3 図）凸凹ワイヤ巻付状態

次に本機の機能について,カシミヤ原毛の整毛作業に 基いて説明する・(第 2 図参照)

カシミヤ山羊から剪り採ったままの原毛は, 剌毛(剛 毛), 万ぶ毛 (柔毛) 拉よびフケが混在しているから,こ れを洗毛してから，三者を分離して紡績原料となる5ふ 毛のみを適当に集める作業を整毛作業とい5.

フィードローラを経てディッシュプレートとテーカ インのケ゚ージ点に沶いて解毛された原料は, 一部はテー カインのワイヤに引っかけられて輸送されるが, 大部分 はゲージ点から噴出されて,テーカインの回転によって 


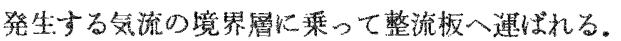

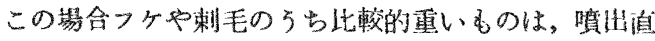
後強制落下の状態になるむのと境界層に乗って整流板先

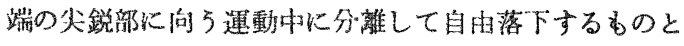
に分れる，3占毛,剩毛の中比較的細いもの，軽いるの， 5ぶ毛にからまって残った微小なフケ類等は整流板に達 し,この先端尖鋭部に和いてフケは完全に分離されて落 下し，桻毛歹大部分㤋分離されるが，5ぶ毛にからみつ いた状態のるのは，ちふ毛とともに整流板の下面直線部 に沿って進行する。その途中に挆いて原料が氮流に乗。 た賟動状態にある場合も，剌毛やフケ類の分離は伴なっ ている。かくして十分汇分離されたう㤎毛と最後まで残 ったごく軽い剌毛は浮遊進行しつつ整流翼まで達する と、ここK発生している上界気流によって，5年毛は整 流板之整流翼の間を上舁するすの，あるいは整流翼の前 方端に损いて方向転換して上年するるのにわかれ進行す るが，刺毛は自然落下する。上升したうぶ毛はケージ ローラの服引力炕よってデリベリえ輸送される。

以上の機能の説明のこ゚とく, 本機の生命忟運転中の気 流状態にあるが，前記の機棈上の要点数項の関係が直接 気流状態に影響して、ひいては整毛效率，品買面に鋭敏 にあらわれてくる。

たとえば整流板の設圆位圈に関する实験結果(性能寒 驗結果はすべて第2 報以降に和いて報皆する）にる と，分離效率を良くするためには，整流板の設谓位置に 䋇ける氮流にでさるだけ水平通路をとらしめることが要 点となる.そのためには第2図でかかるように、デーカ インの垂直軸線上に整流板の先端尖鋭部が位圈するよう に設置しなければならない。

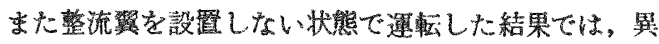
物(赖毛、フケ類) の上く分離された ローラ面に吸引されることなく、ボックス内を浮遊進行 してハッックシート付近に落下堆積する.したがって整

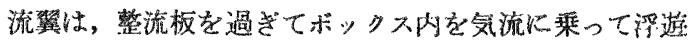
進行する5ら毛を方向転換也しめて，ケ・ジローラの

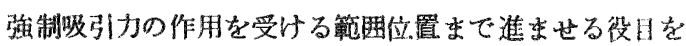
果しているわ防です。

さらにまた本機の性能上の大さな特長の一つにめげら れることは，用途によっては整毛品に適昜の細い剌毛を 含有せしめねばならぬ場合があるが，この場合本機に持 いては、テーカインと整流板先端尖鋭部閒ゲージの加減 と，整流翼を左右上下に謂節なることによって，柾毛含

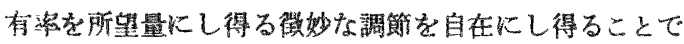
るる。

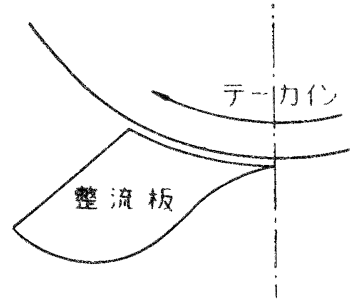

(A)

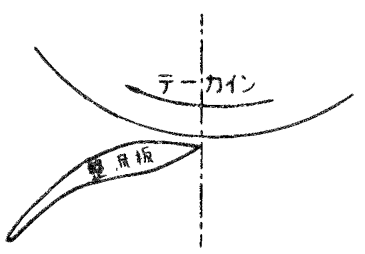

(C)

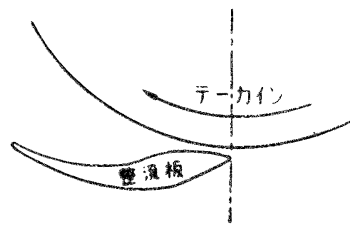

(B)

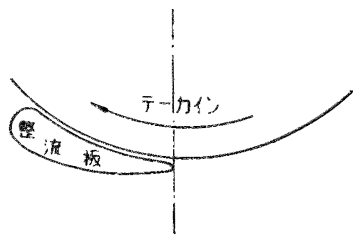

(D)

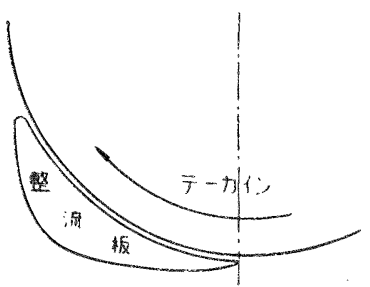

(E)

（第4図）整流板の形状与設琵位置

これらはいずれる本機内の気流状熊火影響を与亮。性 能を左右する機構上の例である。

な招紡績用カシミヤ原料として1級品以規定されてい る剌毛含有率 $0.5 \%$ 以下の整毛品は。一般に用いられて いる整毛用カートに和いては，6〜8山（6〜8工程） を通してい五現状であるが，本機は1回撕で桻毛含有率 は 1.3〜1.5\%になり,フク類ははぼ完全に分離除去で きて，2回挂（2工程）では常に0.5\%以下の1敉整毛 品を紡出することがでる。

〔注〕本機の実驗途上に和いて使用した種々の整流板 の形状とデーカインとの関係位琵の中，主なる bのの例学第 4 図 (A)，(B)，(C)，(D) 拐 よび（E）に参考のためににかかげる、第2圂 以用いられているものは，整流板が(E)，整流

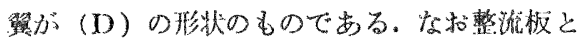
デーカインの関绿位置については、デーカイン の垂直軸線老中心として，矢の前後いろいるの 位犆に設置した嚗合について子奏驗を行なった

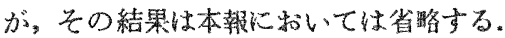

\section{3. カシミヤ原毛の物理的特性}

カシミヤ原毛には，うぶ自と剌毛が混在しているが， 
（第 11 表）

\begin{tabular}{|c|c|c|c|c|c|}
\hline 項 & $\underbrace{\text { 種 }}_{\text {目 }}$ & 類 & 刺 & ぶ 毛 & ケ \\
\hline 緎 & 維 直 & 径 & $5 \times 10^{-3} \mathrm{~cm}$ & $1.5 \times 10^{-3} \mathrm{~cm}$ & - \\
\hline 緎 & 維 & 長 & $5 \mathrm{~cm}$ & $2.5 \mathrm{~cm}$ & - \\
\hline 比 & & 重 & 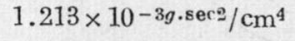 & $1.321 \times 10^{-3 g . \sec 2} / \mathrm{cm}^{4}$ & $1.934 \times 10^{-3 g .5 e c 2} / \mathrm{cm}^{4}$ \\
\hline 重 & & 量 & $1.187 \times 10^{-7} \mathrm{~g}$ & $0.580 \times 10^{-8} \mathrm{~g}$ & - \\
\hline 巻 & 縮 & 性 & ᄂ & あ $\quad \eta$ & - \\
\hline
\end{tabular}

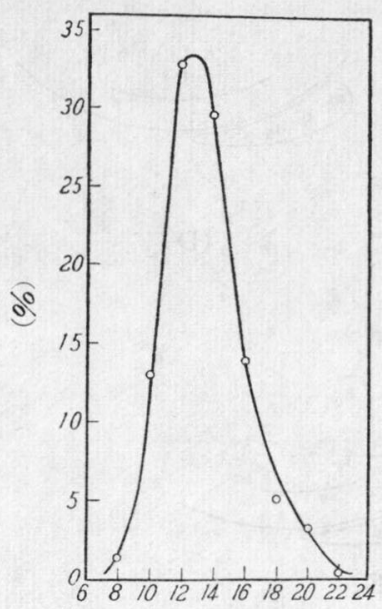

( $\mu$ )

(第 5 図) 万ぶ毛の直径頻 度分布曲線

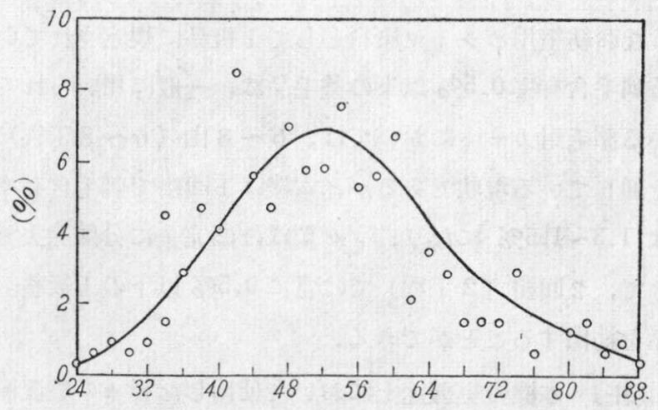

$(\mu)$

（第6 図）刺毛の直径頻度分布曲線

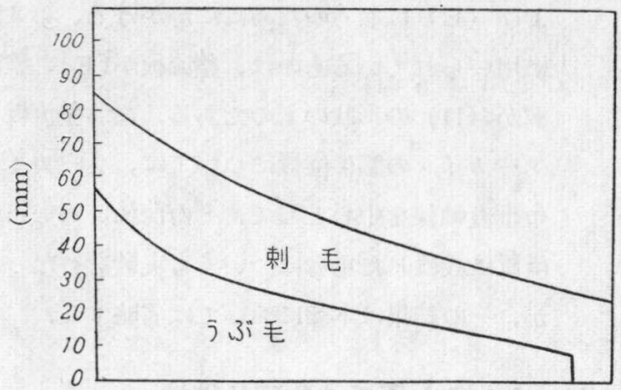

(第 7 図)

刺毛，らぶ毛のステープル ダイアグラム
果を示したものである.

第 5，6，7図拉よび第 1 表からわかるよ5に，剌毛 と 5 ぶ毛の平均瀻維長の比は 2 対 1 であるが, 平均瀻維 直径においては，剌毛は5ぶ毛の約 3.5 倍である。しか も刺毛の直径の変動率は5 ら゙毛のそれに比べてかなり大 きくなっている.これは混在している両者の分離の困難 さの原因の一つであろ5.なお比重は刺毛よりも5 ら゙毛 が大きいが，重量比は約 20 対 1 といら大きな開きで刺 毛が重い.

\section{4. 分離作用の流体力学的考察}

ニューマチックアナライザの“はたらき”は，機構 上の総合効果が気流状態に鋭敏に影響し，その気流の作 用によって纎維中の異物の分離除去にすぐれた効果を出 していることは前述の通りである.したがって本機全体 を一時に分析検討してその作用に流体力学的の裏付けを することは極めて困難である。そこでわれわれは，本機 を部分的に単純な姿として各部ごとに実驗的あるいは理 論的に検討を加え，最後にそれらを総合して機能全体を 推定する研究方針で進めて行くことにした.

なお第 1 図に示す実用機は,実驗上写真撮影,計測等に 困難を伴ない十分なる実験効果を挙げることができない ので，実用機の要部と同構造の同一寸度割合（たたしし機 台の有效幅は実用機の 40 in に対して $12 \mathrm{~cm}$ である) に し，から側面は透明アクリライト板張りとした実驗用ア ナライザ機を製作した. 第 8 図はその外観写真を示す.

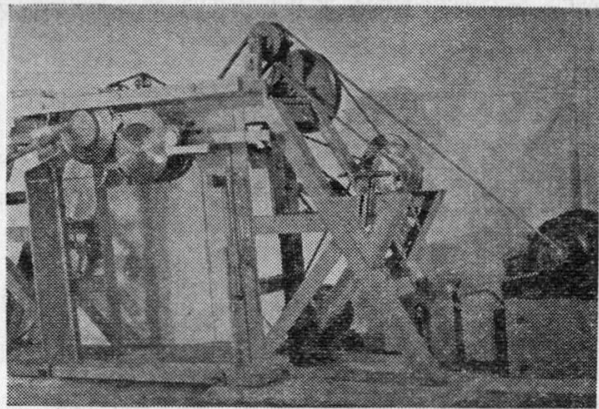

（第8困）実験機外钼 写真 
なず㵶維の存在を教虑せずに整気のみの運動を実驗的 に調べた結果を報告する。

〔注〕懒度分布の測定㳉すへて熱霞対風速計による。 第9図は，速度分布の測定位管および記号を示した略 戍，第 10 図は横蟿にテーカイン面からの高さ $y(\mathrm{~mm})$, 縱軸深备度 $\left(\theta^{\circ}\right)$ に和ける速度分布の無次元量 $u / U_{0}$ として境界層の発達状態を示したるの，第11成は境界

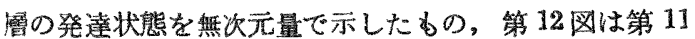
図の $\theta=135^{\circ}, 150^{\circ}$ における測定值のみを別図にしたる のである。

第 11, 12 四の実線は理諭線を示すもので，境界厤の発

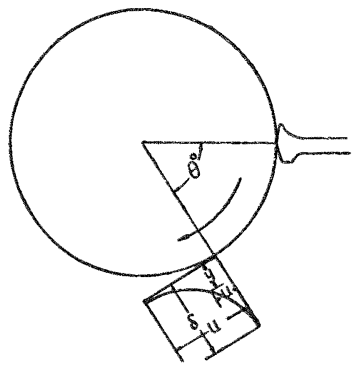

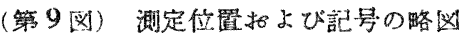

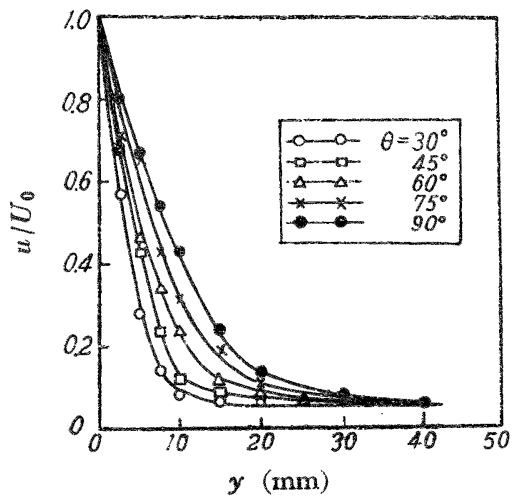

（第 10 図） $u / U_{0}$ \& $y$ の関係

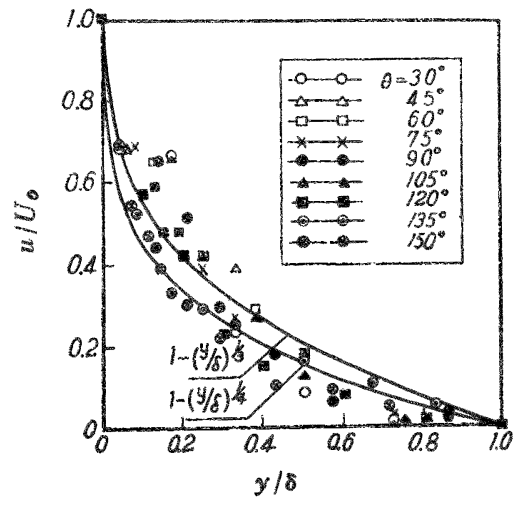

(第 11 这) u/U。 と $y / 8$ の哭保
遂が比較的安定した $\theta=135^{\circ} ， 150^{\circ}$ に持いては，测定俻 が $1 / 4$ 乗則によく一致すると云光る。

第13図は，整流板，整流翼ともに取りはすした場令 の風速分布形，第14図は整流板を設監し整流翼を取り はずした場合の風速分布形，第15因は整流板，整流算 ともに設置した場合の風速分布形を示す。

これらの罒から笑流のみの運動を見ても，前述の分離 現象の抽爱的な説明飞和ける，整流板括よび整流翼の分 離作用に拈よぼしている効果を理解できると思う。

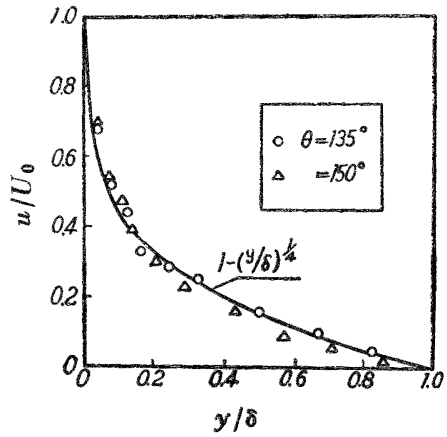

（第 12 区） $u / U_{0}$ と $y / \delta$ の関係

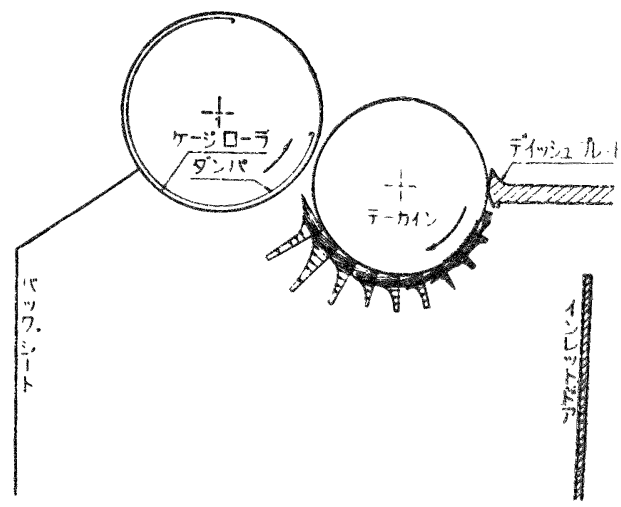

(第 13 区)

栭遴分布形（整游板，整流翼共なし）

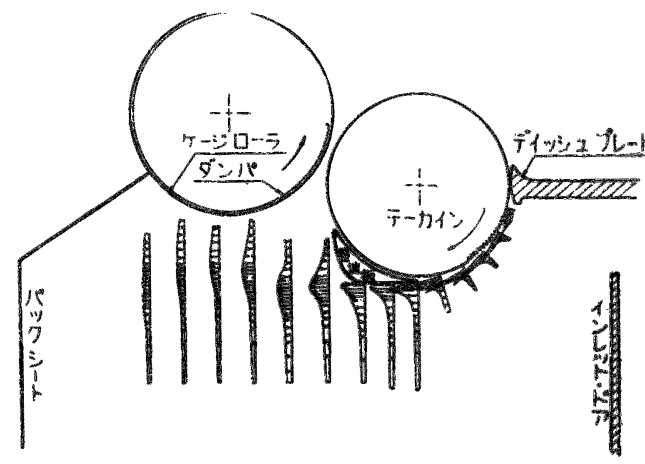

(第 14 四)

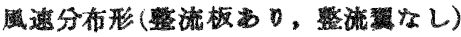


第 16 図はディッシュプレートから整流板先端まで, 第 17 図は整流板先端尖鋭部付近，第 18 図は整流板およ

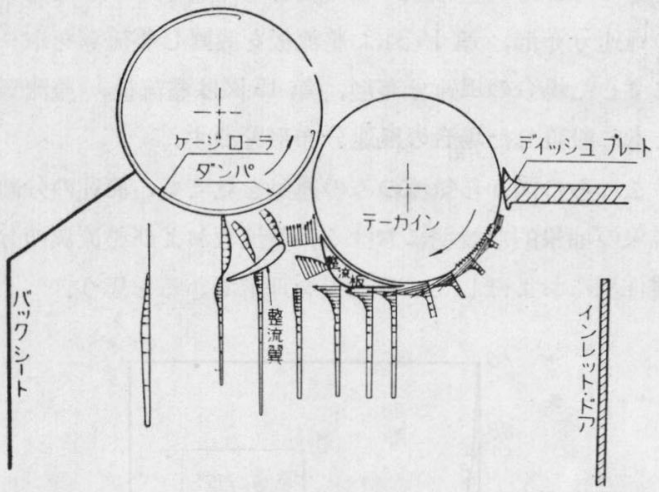

（第 15 図）

風速分布形（整流板，整流翼共めり）

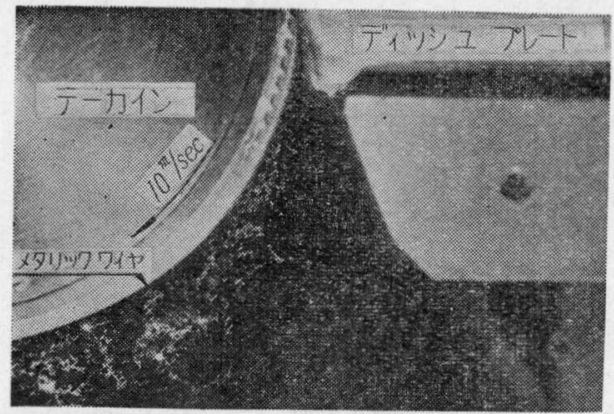

（第16図）繊維の分離，飛散状態

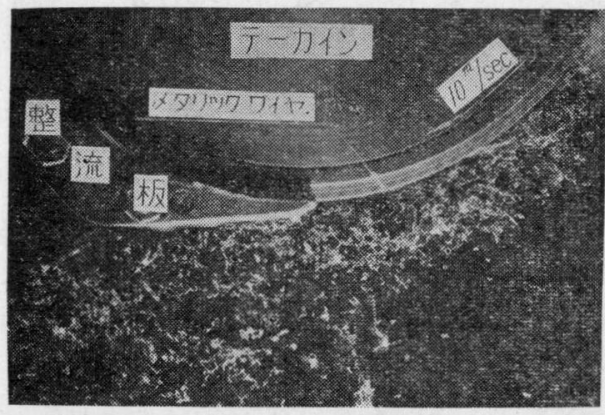

（第17図） 繊維の分·離, 飛散状態

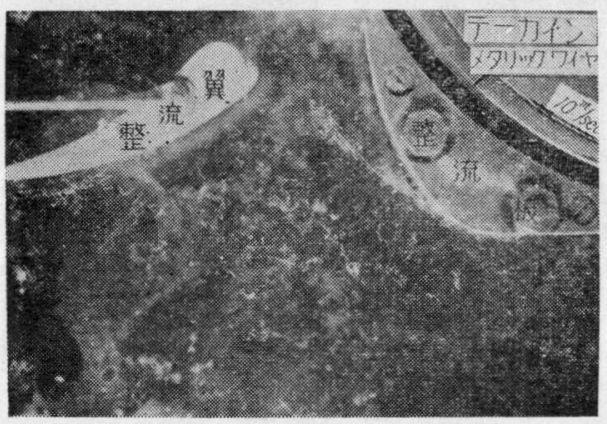

（第18困）繊維の分離, 飛散状態
び整流翼付近に拈ける纎維の飛散, 分離状態の瞬間写真 を示す.このそれぞれの写真は, 実験機のテーカイン周 速を $10 \mathrm{~m} / \mathrm{sec} に し て ， 70$ s ノイルに虽光漂白をほどこ した原料をかけた場合の瞬間撮影であって，整流板，整 流翼を取り付け,ケージ ローラ内に強制吸引力を与え， 完全な機能状態で運転した場合のものである.

先に機能上から分離現象を抽象的に説明したが，そこ では軽い纎維は境界層に乗って前方へ進み，重いものは 落下すると述べた。

これる力学的に説明するならば, 㵶維に拉よぽす気流 の抵抗と繊維に動く遠心力との釣合いにおいて，前者が 勝るものは気流に乗り, 後者の勝るものは境界層外へ飛 ばされてボックス内に落下すると云える。

S. M. Freeman と A. Linnert が 1956 年に発表した 論文「シャーレオープナに関する除じん概論」によれば 速度こ 5 配が $200 \mathrm{ft} / \mathrm{sec} /$ in の場合, 繊維に対する重力, 遠心力および空気力学的力の大きさの比はそれぞれ 1 : $100: 5000$ であるから重力や遠心力は無視でさると述べ ているが, 空気力学的力の定義としてせん断応力を取る ことには疑問がありまた W. Walton は同じくシャー レオープナに関する論文の中で, ビータ回りの境界層の 発達および遠心力の問題を考えるためにビータ速度と空 気速度を取り上げて，分離（除じん）にはこの 2 要素は 見逃し得ないものであると指摘している.

著者等は一応遠心力と空気抵抗の 2 要素のみについて 分離現象の考察を進めることにする.

既述の S. M. Freeman および A. Linnert すとの論 文の中で述べているが，空気による分離を考察する上に おいて，空中に拈ける纎維および異物の浮力の差が重要 なる要素となる。この浮力は物体が静止空気中を落下す る際の終末速度 (後述) が小さい程大きいのである.

以下桶口の式を引用して㵶維の運動を論じることを試 みる.

\section{（1）自由落下の終末速度}

繊維のような比較的小さい物体を静止空気中に自由落 下させると，その落下速度は比較的小で，しかも短時間 で重量と空気抵抗が釣合って，それ以上速度は増大しな い.この時の速度を自由落下の終末速度と呼ぶ。

記 号 (重力単位)

\begin{tabular}{|c|c|}
\hline$w_{0}(\mathrm{~g})$ & : 纎維の真の重量 \\
\hline$w(\mathrm{~g})$ & : 繊維の空気中の見掛の重量 \\
\hline$m\left(\mathrm{~g} \cdot \mathrm{sec}^{2} / \mathrm{cm}\right)$ & : 繊維の質量 \\
\hline$d(\mathrm{~cm})$ & : 緎維の直径 \\
\hline$g\left(\mathrm{~cm} / \mathrm{sec}^{2}\right)$ & : 重力の加速度 \\
\hline
\end{tabular}


$Z(\mathrm{~cm}) \quad$ : 繊維の落下距鹳

$u_{\mathrm{s}}(\mathrm{cm} / \mathrm{scc})$ : 緎維の落下速度

$u_{0}(\mathrm{~cm} / \mathrm{sec})$ : 緎維の落下初速度

$t(\mathrm{sec}) \quad:$ 経過時間

$C_{D}(/)$ : 緎維の空気抵抗係数

$W(\mathrm{~g} / \mathrm{cm})$ : 㵶維の空気抵抗

$\rho_{S}\left(\mathrm{~g} \cdot \mathrm{sec}^{2} / \mathrm{cm}^{4}\right):$ 䌦維の密度

$\rho_{f}\left(\mathrm{~g} \cdot \mathrm{sec}^{2} / \mathrm{cm}^{4}\right)$ : 空気の密度

$g^{\prime}\left(\mathrm{cm} / \mathrm{sec}^{2}\right)$ : 見掛の重力の加速度

$u_{m}(\mathrm{~cm} / \mathrm{sec})$ : 自由落下の釉末速度

い覚量 $m$, 真の重量 $w_{0}$ ，見掛计の重量 $w$ の㵶維 が管気中を落下速度 $u_{S}$ で自由落下するとき, その空気 抵抗 $W$ と空気の浮力を考慮に入れた重力の加速度 $\mathrm{g}^{\prime}$ か ら求められる力とのつり合を考えると、時間 $t$ に関して 次の運動方程武が導かれる。

$$
\begin{aligned}
& m \frac{d u_{g}}{d t}=n \cdot g^{\prime}-W \\
& g^{\prime}=\left(\rho_{s}-\rho_{f}\right) g / \rho_{s} \\
& w=w_{0}\left(\rho_{S}-\rho_{f}\right) / \rho_{S}=m \cdot g\left(\rho_{S}-\rho_{f}\right) / \rho_{S} \\
& W=C_{D} \cdot d \cdot\left(\rho_{f} \cdot u_{S}^{2} / 2\right)
\end{aligned}
$$

時間の経過とともに落下速度の增大，したがって等袈

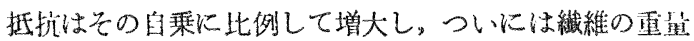
と釣合らことになる。すなわら（1）物よび（2）式から

$$
\begin{aligned}
& m \frac{d u_{\varepsilon}}{d t}=m \cdot g^{\prime}-C_{D^{*}} \cdot\left(\frac{\rho_{f} \cdot u_{m}^{2}}{2}\right)=0 \\
& \therefore u_{m}=\sqrt{\frac{2 w}{C_{D} \cdot \rho_{\mathcal{J}} \cdot d}} \quad \ldots \ldots \ldots \ldots \ldots \ldots \ldots
\end{aligned}
$$

となる。

(2) ニューマチックフナライザの分離作月

既述のよ5に本機の作用を論議する上打いて, 整流 板および整流翼の働きを見逃すことはでさないのである が、いまここでは両者执よびケージローラの強制吸引力 のない場合について,ディッシュプレートのゲージ点を 出てからの剌毛拈よび5ぶ毛の運動を考察して見よ5。

(a) 瀻維がテーカインによる境界層に莱った場合 テーカインの回転速度が比較的早く、それによる遠心

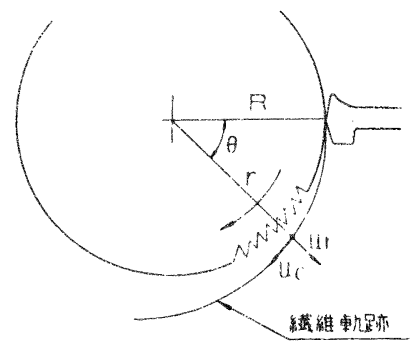

(第 19 図) 緎維軌 跡模型
クが大きくて再力の影響を無視できるならば，艺の遭動 を淪ずるのは制合簡単になる。

いま第 19 四のよ 5 以, 瀻維が $\theta=0$ K拈いて半径 $R$ 垈加出発し， $\theta=\theta$ に数いて半径 $r$ 上にあるとして, 䎻方向の速度を きの㵶維の軌跡を求めて見よ5。

いま緎維の自由落下の終末速度に比べて, 空気速障が 相当に大きく，したがって織維速度と空気速度が等しい とすると，空気抵抗と遠心力のつり合から

$$
m \cdot r \cdot \omega^{2}=C_{D} \cdot\left(\frac{\rho_{\mathcal{T}} \cdot u_{r}^{2}}{2}\right) \cdot d \cdots
$$

ただし $\omega(\mathrm{rad} / \mathrm{sec})$ : 角速度 となる。（4）式に（3）式の終木速度を代入して整理す ると，

$$
u_{r}=u_{m} \cdot \sqrt{\frac{r \cdot \omega^{2}}{g^{\prime}}}
$$

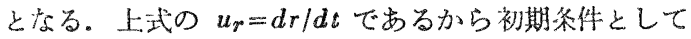
$t=0$ にて $r=R$ として積分すると

$$
r=R\left(\frac{u_{m}}{2} \cdot \sqrt{\frac{\omega^{2}}{g^{\prime} R}} \cdot t+1\right)^{2}
$$

となり，（6）式が回転体によって生或る境界管内を飛 行する繊維の軌跡を示す式である。

抵抗係数は，著者等が風洞実験によって求めた值を使 用する。(これについては「平面板状メタリックワイけ の特性第 2 報，山脇，長雪」で詳報する）

第 20 図は、レイノルズ数と繊維の抵拐係数の関係を 測定傎ら求めたものである。

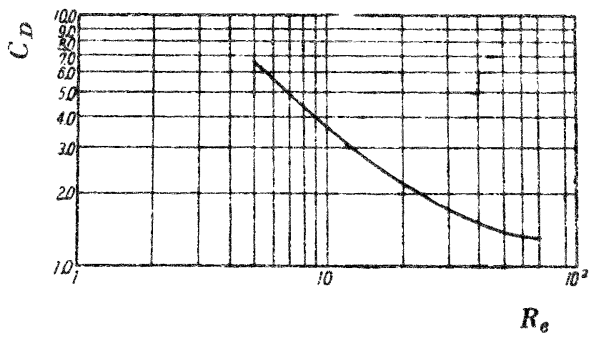

（第 20 図）蟣維の抵抗 俰数

第20図に示されている抵抗係数は，緎維の長さうj间 汇対して $90^{\circ}$ の方向から気流が当った場合であるが，实 際には瀻維は等気流に乗っているものであり、したがっ て抵抗值としては切線方向の值を用いるのが適当と思る れる。

C. Mack, E. J. L。Smart によれば，緎維が気流飞䞑 して $90^{\circ}$ の角をなす場合と、気流に平行な湯合との想抗 比は約 10 刘1である。

以上のことを考虑に入れて，（6）式から瀻維の旋回 


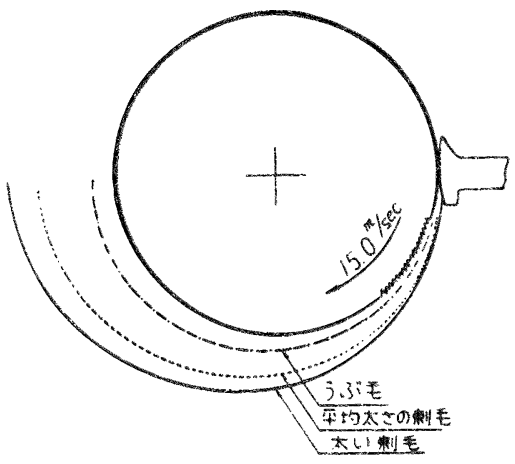

(第21図) カシミヤ緎維の飛行軌跡

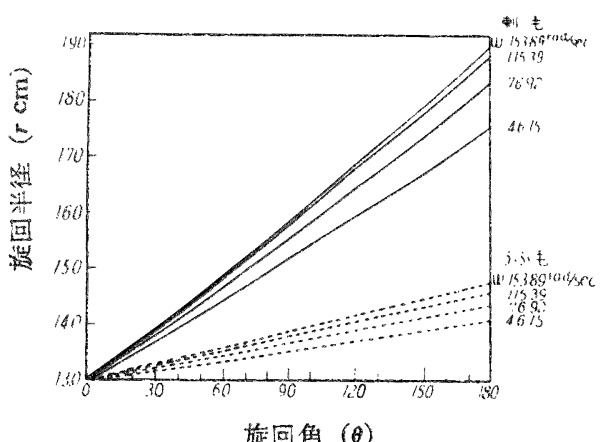

（第 22 困）侮速度による旋回半径の梘違

半径を計算図示したすのが，第 $21 ， 22$ 図である.

第 21 図はテーカインの周速度を実用機の常用周速度

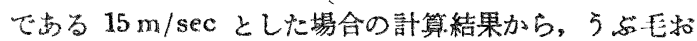
よび剌毛の飛行轨跡の相違を四示したすのである。

第 22 図は、テーカインの角速度を $153.89 \mathrm{rad} / \mathrm{sec}$ (周 速度は $20 \mathrm{~m} / \mathrm{sec}), 115.39 \mathrm{rad} / \mathrm{sec}(15 \mathrm{~m} / \mathrm{sec}), 76.92$ $\mathrm{rad} / \mathrm{sec}(10 \mathrm{~m} / \mathrm{sec}), 46.15 \mathrm{rad} / \mathrm{sec}(5 \mathrm{~m} / \mathrm{sec})$ として それ爷れ計算した場合のうぶ毛と剌毛の旋回半径の違い

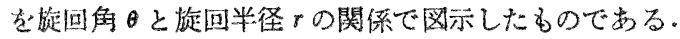

この図からかかるように，周速度が $15 \mathrm{~m} / \mathrm{sec}$ と 20 $\mathrm{m} / \mathrm{sec}$ の場合の旋回半径の違いはわずかである。したが って計算結果から分離効果を見れば、テーカインの周速 度は $20 \mathrm{~m} / \mathrm{sec}$ 付近にする必要はなく $15 \mathrm{~m} / \mathrm{sec}$ が大体 適当しているるのと考えられる。

（b）繊維が境界層に乗らないで落下する場合

ディッシュプレートのゲージ点から出た㨁後化捻い ては、テーカイン比よって発生する境界層の発達は小さ く、したがってこの境榃倜に乗らない瀻維もある。この ような瀻維の運動は、テーカインの表面速度を初速度と する強制落下として职り报点ばよい。

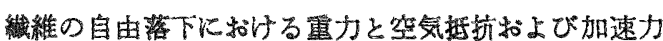
のつり合の式は（1）および（2）式から

$$
m \cdot \frac{d u_{s}}{d t}=m \cdot g^{\prime}-C_{D} \cdot d \cdot\left(\frac{\rho_{f} \cdot u_{s}^{2}}{2}\right)
$$

であるが, $t \rightarrow \infty$ で $m \cdot g^{\prime}-C_{D} \cdot d\left(\rho_{f} \cdot u_{s}^{2} / 2\right)=0$ である から

$$
\frac{d u_{S}}{u_{m b}^{2}-u_{S}^{2}}=\frac{g^{\prime}}{u_{m}^{2}} d t
$$

となる。そこで落下速度 $u_{S}$ を時間 $t$ とついて解き， $t=$ 0 Kて $u_{S}=u_{0}$ の初期条件を入れ， $u_{0} / u_{m}=a$ として積 分すると

$$
\frac{u_{s}}{u_{m}}=\frac{\left\{1-e^{-2 r}\left(\frac{1-a}{1+a}\right)\right\}}{\left\{1+e^{-a r}\left(\frac{1-a}{1+a}\right)\right\}}
$$

となる.ここにおいて $\tau$ は $g^{\prime} t / U_{m} て ゙$, 時間の無次元 量を示す。

また落下距離 $Z$ 桜

$$
u_{S}=\frac{d Z}{d t}=u_{m} \cdot \frac{\left\{1-e^{-2 \frac{g^{\prime} t}{u m}}\left(\frac{1-a}{1+a}\right)\right\}}{\left\{1+e^{-2 \frac{g^{\prime} t}{u m}}\left(\frac{1-a}{1+a}\right)\right\}}
$$

に执いて, 初期条件 $t=0$ にて $Z=0, u_{S}=u_{0}$ を入れて 積分すれば

$$
\frac{2}{u_{m} \cdot t}=\frac{1}{\tau} \log \left\{\frac{1+k \cdot e^{-\Omega \tau} \tau}{1+k}\right\}+1
$$

ただし $k=\frac{1-a}{1+a}$

となる。

第 23 因は (7) 式から求めた経過時間 $\tau\left(=g^{\prime} t / u_{m}\right)$ 々落下速度比 $u_{S}{ }^{\prime} u_{m}$ の関係（共に無次元量），第 24 図 は剌毛々 5 ふ毛別に，第 23 因の関係を落下時間 $t$ と落 下速度 $u_{S}$ の関係で示したものである.

第 25 四は（8）式から求めた経過時間 $\tau$ と落下距離

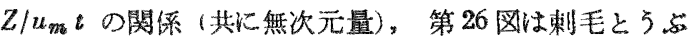
毛別飞，第 25 函の関係を落下時間 $t$ 之落下距離 $Z$ の 関䋆で示したものである。（破線は横軸，縦軸のかっこ

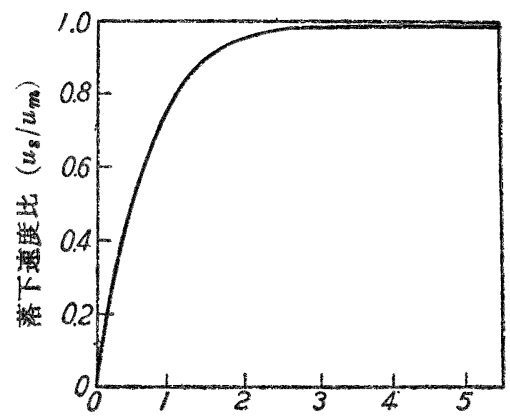

経過時間 $\boldsymbol{r}\left(g^{\prime} t / u_{m}\right)$ （第 23 四） $\tau$ そ $u_{g} / u_{m}$ の関保 


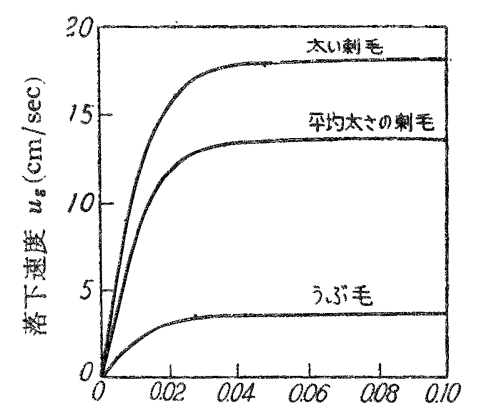

落下時間 $t(\mathrm{sec})$

(第 24四) $t$ \& $u_{8}$ の関係

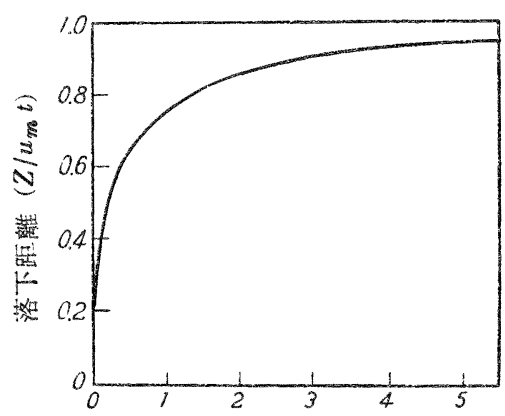

経逻時間 $\tau\left(g^{\prime} t / u_{m}\right)$

(第 25 図) $r z Z / u_{m}$ t

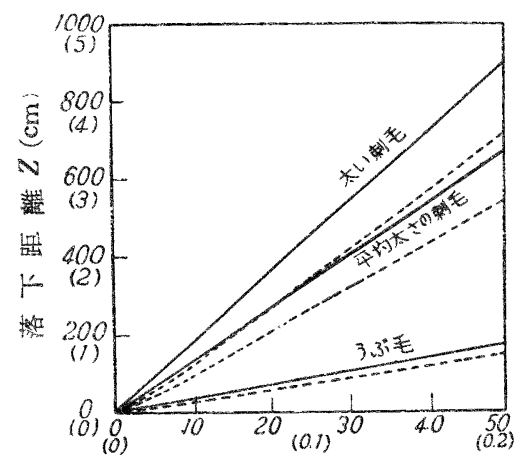

落下時間: $(\mathrm{sec})$

(第 26 因) $t$ z $Z$ 関係

内数字单拉儿上る関係を示す)。

これらの因から，落下緎維はきわめて短時間内に等述 遇動となり，その速度も小さい值ですり，かつ5ぶモる

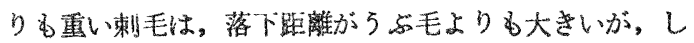
かしその絶対值は小さいことがわかる。

したがって結果としてはボックス内に発生している鰂 環流の速度の方が大となり分離落下途上の瀻維を再度浮 上せしめることとなる。この現能は実用機においてる实
験機に和いても運転中にしばしば経驗与ることである。 このように分離落下途上の㵶維が，逆に浮上して境界 層へ混入し，良瀻維汇混合することを防止するなめに， ボックス底板部に循環流を消去せしめる方法を講じたり 設計上ボックス内深さ之奥行の比を检討する等に関して 以上の計算は有効である。

\section{5.結睑}

以上の結果を要約すれば次のようになる。

（1）テーカインの速度分布の测定値は， $1 / 3$ 保則もし くは 1/4 栱則曲線のいずれかに大体一致する。

(2) 要部の風速分布形の確立によって, 整流板扣よ び整流翼の気流状態に与える效果を確認し得 た。

（3）緎維（羊毛ノイル）をかけた場合の要部の瞬間 写真によって，分離作用に和ける瀻維举動を推 测することがでさる。

（4）同上写真の緎維飛散状態の計測による境界層の 発達と風速分布形(第13図)に示されるそれと は大体一致する。

(5) 桶口氏の理論式の連用によって,テーカインの 回転によるカシミヤ原料中り剌毛和よびうら゙长 の飛行軌跡学明らかにすることがでさた。

(6) ボックス内樑さ対奥行の関係の設部上の検討指 針学得大。

（7）ボックス内底板部に循環流消去方法を請ずすこ との必要性がわかった。

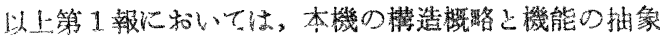
的な説明亚びに一部奏験的，理諭的考察を行った結果を 報告したが，実騃結果と理諭の比較考察，分離作用の流 体力学的総合考察, カシミヤ原毛の整毛実験結果の具体 的資料等以ついては，第2 2 報以降汇扣いて坏告する。

\section{文献}

1) 从脇，正埴；本誌，10，163(昭32)

2) 藤本武助; 流体力学, 第 3 版, 334 (1956)

3) C. Mack, E. J. L. Smart; J. Text. Inst., 4, T 359 (1954)

4) S. M. Freeman, A. Linnert; J. Text. Inst., Vol. 48, No. 2, T 54 (1957)

5) 桶口; 本鮚, 11-452, 533, 752 (昭 33)

蟣学綕, 14-1, 26 (昭33) 